Acta vet. scand. $1973,14,366-380$.

From the Department of Medicine I, Royal Veterinary College, Stockholm, Sweden.

\title{
IMMUNOGLOBULINS IN NORMAL PORCINE TRACHEOBRONCHIAL SECRETIONS*
}

\author{
By \\ Nils Holmgren
}

HOLMGREN, NILS: Immunoglobulins in normal porcine tracheobronchial secretions. Acta vet. scand. 1973, 14, 366-380. - Methods of collecting sputum and tracheobronchial washings are described.

Proteins in normal porcine tracheobronchial secretions are studied by immunochemical qualitative and quantitative methods. Among the immunoglobulins, IgA, IgG and IgM are identified. Immunoelectrophoretic analysis of sputum shows albumin, transferrin and in the $\alpha$-region 2 components not found in serum. The predominant immunoglobulin in tracheobronchial secretions is IgA, which accounted for about $85 \%$ of the total immunoglobulin concentration in sputum and $61 \%$ of the immunoglobulin concentration in tracheobronchial washings.

immunoglobulins; pigs; tracheobronchial secret i o n s.

During the last decade the presence of a local immune system resident on mucosal surfaces has been studied intensely in different species. Since the work by Hanson (1961) in Sweden and Chodirker \& Tomasi (1963) and Tomasi et al. (1965) in the United States it is well established that a local humoral immune system exists in human external secretions. An immunoglobulin analogous to human secretory IgA has been isolated from porcine colostrum and milk (Porter 1969, Bourne 1969, Porter et al. 1970, Richardson \& Kelleher 1970, Vaerman et al. 1970), saliva(Bourne), gut mucosa and intestinal juice (Bourne et al. 1971).

The presence of immunoglobulins in the human tracheobronchial tree has mostly been studied in sputum during pathological conditions. The secretion from the normal tracheobronchial tree is scanty in amount and difficult to collect. Most in-

* Supported by the Swedish Council for Forestry and Agricultural Research. 
vestigations have therefore been performed on tracheobronchial washings collected during anaesthesia (Keimowitz 1964, Masson et al. 1965, Turgeon et al. 1969, 1971).

Immunoglobulins have been studied in canine sputum collected undiluted in a surgically prepared tracheal pouch (Lieberman et al. 1970).

The aim of this study is to investigate the proteins in normal porcine tracheobronchial secretions by immunochemical qualitative and quantitative methods, with special reference to the immunoglobulins.

\section{Animals}

\section{MATERIAL AND METHODS}

Sputum and tracheobronchial washings were studied in 9 pigs of Swedish landrace. The pigs were about 6 months old. They were delivered from a stockfarm which for the last 15 years has been free of Swine Enzootic Pneumonia and other contagious respiratory diseases. All post-mortem examinations including microscopic investigations of the lungs from the 9 pigs showed normal conditions.

\section{Collection and processing of specimens}

The pigs were anaesthetized by intravenous injections of nembutal sodium and placed in a recumbent position on an operation table. An incision was made in the skin from the cartilago cariniformis to the larynx. The trachea and larynx were dissected in a blunt way in order to avoid bleedings. The trachea was lifted up and cut off behind the larynx. Sputum was collected by inserting a piece of cotton held by a forceps into the carina, where the cotton was soaked in sputum. The cotton was then immediately put in a plastic syringe $(1 \mathrm{ml})$. The tip of the syringe was sealed with a rubber cork. The sputum samples were stored at $-70^{\circ} \mathrm{C}$ until analysed. Sputum was collected by squeezing the cotton in a syringe.

\section{Collection of tracheobronchial washings (TBW)}

A rubber cork penetrated by a $15 \mathrm{~cm}$ plastic tube was fixed in the trachea with ligatures, so that the pig was breathing through the tube. Twenty $\mathrm{ml}$ of PBS (phosphate buffered saline, pH 7.4) 
was injected through the plastic tube with the pig in a horizontal position. Then the operation table was lifted, so that the pig was placed in a vertical position with the head downwards. TBW was collected from the plastic tube into a $100 \mathrm{ml}$ Erlenmeyer flask. The procedure was repeated 9 times. The TBW was homogenized in a Potter-Elvehjem homogenizer for $20 \mathrm{~min}$. and centrifuged at 5700 r.p.m. for $20 \mathrm{~min}$. The supernatant was concentrated with polyvinylpyrrolidone (PVP) about 50 times and stored at $-70^{\circ} \mathrm{C}$ until analysed.

Preparation of IgA from sow's milk

The method of Bourne (1969) was used with some modifications. Milk was collected 12-15 days after partus from 3 different sows. The milk was pooled and the fat removed by centrifugation at 15,000 r.p.m. for $15 \mathrm{~min}$. at $4^{\circ} \mathrm{C}$. The casein was centrifuged down at 15,000 r.p.m. for $3 \mathrm{hrs}$. at $4^{\circ} \mathrm{C}$. Lipoprotein was precipitated by adding $0.02 \mathrm{ml}$ of a $10 \%$ (w/v) dextran sulphate 500

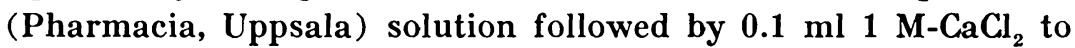
each $\mathrm{ml}$ of the milk. The precipitate was sedimented by centrifugation at 15,000 r.p.m. for $15 \mathrm{~min}$. at $4^{\circ} \mathrm{C}$. The supernatant was dialyzed against distilled water and then against $0.5 \mathrm{M}$ Tris$\mathrm{HCl} 0.15 \mathrm{M}-\mathrm{NaCl}$ buffer ( $\mathrm{pH} \mathrm{8.1}$ ). One hundred ml of this milk serum was separated on Sephadex G 200, column size $9 \times 97 \mathrm{~cm}$, with reverse flow $80 \mathrm{ml} / \mathrm{hr}$. The fraction volume was $10 \mathrm{ml}$. $0.5 \mathrm{M}$ Tris-HCl $0.15 \mathrm{M}-\mathrm{NaCl}$ buffer was used for elution. The second part of the first peak was pooled and dialyzed against distilled water and concentrated about 10 times with PVP. After dialysis against $0.15 \mathrm{M}$ Tris- $\mathrm{HCl}$ buffer ( $\mathrm{pH} 7.4$ ), the concentrated fraction was chromatographied on Sephadex DEAE A 50, column size $2.5 \times 46 \mathrm{~cm}$, flow rate $16 \mathrm{ml} / \mathrm{hr}$. and fraction volume $10 \mathrm{ml}$, with stepwise elution using Tris- $\mathrm{HCl}$ buffers $0.15 \mathrm{M}, 0.2 \mathrm{M}, 0.3 \mathrm{M}$, $0.5 \mathrm{M}$, and $0.7 \mathrm{M}$ ( $\mathrm{pH} 7.4$ ). The peaks obtained at 0.2 and $0.3 \mathrm{mo-}$ larity were concentrated with PVP and dialyzed aginst $0.5 \mathrm{M}$ Tris$\mathrm{HCl} 0.15 \mathrm{M}-\mathrm{NaCl}$ ( $\mathrm{pH} \mathrm{8.1)}$. The peaks were run separately on Sephadex G 200, column size $2.5 \times 46 \mathrm{~cm}$, flow rate $10 \mathrm{ml} / \mathrm{hr}$. and fraction volume $10 \mathrm{ml}$. The Tris- $\mathrm{HCl}$ buffer was used for elution. In both cases a single symmetrical peak was obtained. The second part of both peaks was pooled concentrated and re-separated under the same conditions. A single symmetrical peak was obtained. The second half of the peak was used for immunization purposes. 


\section{Preparation of rabbit anti-swine-IgA serum}

On days 1 and $3,0.3 \mathrm{ml}$ of Freund's complete adjuvant was injected into the footpad of a hindleg. On day 7, when lgl. poplitialis was easily palpable, $0.3 \mathrm{ml}$ of aluminium-absorbed $\operatorname{IgA}(0.6$ $\mathrm{mg}$ protein per $\mathrm{ml}$ as measured by u.v. absorption) was injected into the lymph node. This was repeated on days 11,15 and 19. Aluminium-adsorbed IgA was then given i.v. $0.5 \mathrm{ml}$ on days 27 and 28 , and $1.0 \mathrm{ml}$ on days 29 and 30 . An antihistamine (Vetibenzamin, Ciba $0.5 \mathrm{ml}$ i.m.) was given before the i.v. injections to inhibit anaphylactic reactions. Aluminium-adsorption of IgA was performed before each injection by adding some crystals of potassium aluminium sulphate followed by a few drops of $0.1 \mathrm{~N}$ $\mathrm{NaOH}$ to make the solution basic. A heavy precipitate was formed.

Blood was drawn 1 week after the last injection.

Swine IgG and rabbit anti-swine-IgG serum were prepared according to Martinsson (1970). Pure swine IgM and a monospecific rabbit anti-swine-IgM serum were kindly supplied by Dr. A. Jönsson, Dept. Medicine I, Royal Veterinary College, Stockholm.

Pure swine transferrin and a rabbit anti-swine-transferrin serum were kindly donated by Dr. K. Martinsson and Dr. K. Thorén, Dept. Medicine I, Royal Veterinary College, Stockholm. A monospecific rabbit anti-swine-IgA serum was generously supplied by Dr. P. Porter, Unilever Research Laboratory, Colworth House, Scarnbrook, Bedford, Great Britain.

\section{Preparation of rabbit anti-TBW serum}

On days 1 and $3,0.3 \mathrm{ml}$ of Freund's complete adjuvant was injected into the footpad of a hindleg. On day 9, when lgl. poplitialis was easily palpable, $0.2 \mathrm{ml}$ of concentrated TBW $(0.2 \mathrm{mg}$ protein per $\mathrm{ml}$ as measured by u.v. absorption) $+0.2 \mathrm{ml}$ of Freund's incomplete adjuvant were injected into the lymph node. This was repeated on days $15,21,27$, and 33 . On days 43 and 45 $2 \mathrm{ml}$ of aluminium-adsorbed TBW was injected i.v. Antihistamine was given before the i.v. injections to inhibit anaphylactic reactions. Aluminium-adsorption of TBW was performed as with IgA.

Blood was drawn 6 days after the last injection.

Rabbit anti-TBW serum was absorbed with freeze dried swine serum for studies on sputum components not found in serum. Absorption was made until no reaction occurred with swine serum. 
Immunoelectrophoretic analysis was performed according to the method of Scheidegger (1955).

The double diffusion-in-gel technique by Ouchterlony was used in its micromodification (Wadsworth 1957).

The single radial diffusion test was used essentially as described by Mancini et al. (1965). Each sample was determined in doubling dilutions in PBS, which gave 2-4 measurable values from which the mean values was calculated. IgM was measured by using the samples undiluted and diluted 1:2. Duplicate determinations were made for every TBW sample on different plates at different times, and the mean value was calculated. The volume of the sputum samples only permitted single determinations. At least 2 determinations of a control serum were made on each plate.

Reference antigens. IgG was obtained from swine serum according to Martinsson. The protein concentration of the IgG reference antigen was delermined by the micro-Kjeldahl method, and the nitrogen content $\times 6.25$ was regarded as the protein concentration. IgA prepared from sow's milk was used as standard antigen. The protein concentration was determined by the Lowry method (Lowry et al. 1951). IgM was prepared according to Jönsson (to be published). The protein concentration of the IgM reference antigen was determined by the micro-Kjeldahl method, and the nitrogen content $\times 6.25$ was regarded as the protein concentration. The standard curves for the Mancini determinations of IgG, IgA and IgM were drawn with the use of dilutions of the reference immunoglobulins, and the areas of precipitates obtained were plotted against the corresponding concentrations.

Analytical errors. These were calculated from repeated determinations of a control serum on different plates and at different times. The following formula was used: $S^{2}=\frac{n \Sigma x^{2}-(\Sigma x)^{2}}{n(n-1)}$

\section{RESULTS}

Separation of IgA from milk

The results of separation on Sephadex G 200 of porcine milk collected 12-15 days after partus are shown in Fig. 1. Most IgA was eluted in the first peak together with some IgM and before IgG. 


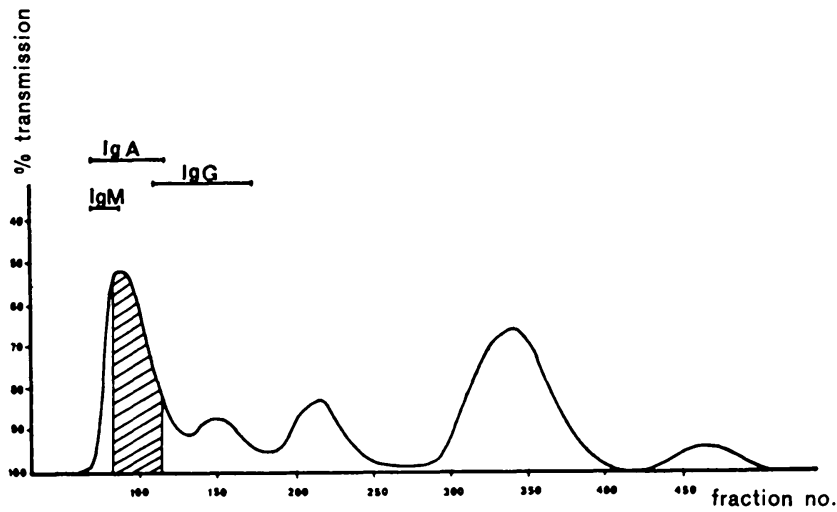

F i g u r e 1. Gel filtration on Sephadex G 200 of porcine milk collected 12-15 days after partus. The curve represents the transmission at $280 \mathrm{~m} \mu$.

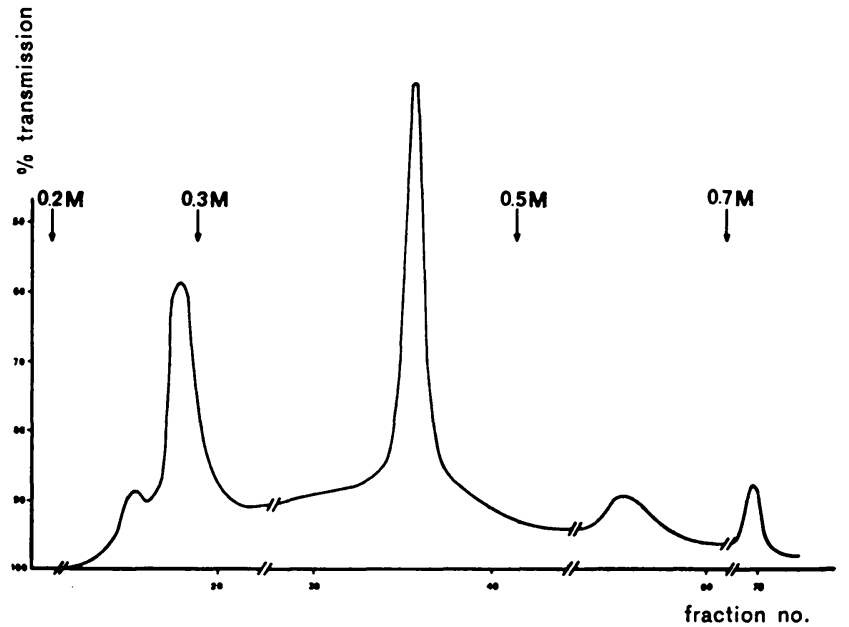

Figure 2. Elution pattern after chromatographic separation on DEAE-Sephadex A 50 of the IgA preparation from gel filtration on Sephadex G 200 (Fig. 1). The curve represents the transmission at $280 \mathrm{~m} \mu$.

The shaded area of the first peak was chromatographied on Sephadex DEAE A 50, and the elution pattern is shown in Fig. 2.

The peaks eluted at 0.2 and 0.3 molarity were run separately on Sephadex G 200, and a single symmetrical peak was obtained in both cases. The second part of these peaks was pooled and reseparated under the same conditions. The result of this final gel filtration is shown in Fig. 3.

Immunoelectrophoretic analyses and immunodiffusion tests 


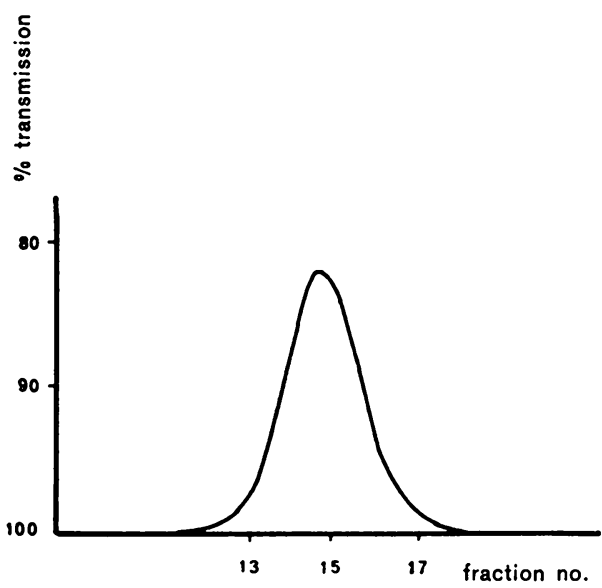

F i g u r e 3. Gel filtration on Sephadex G 200 of the final IgA preparation. The curve represents the transmission at $280 \mathrm{~m} ! \mathrm{l}$.

Fig. $4 b$

Fig. 4a

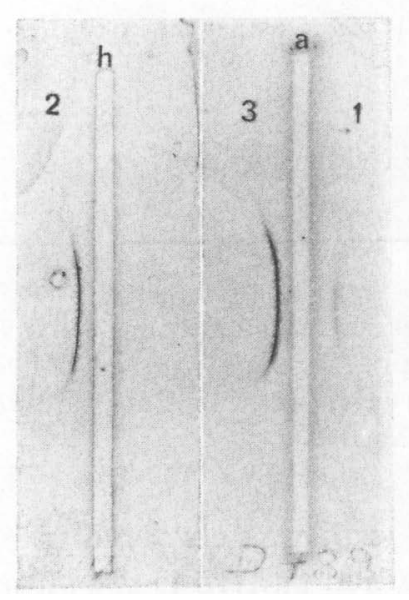

(1) 6

(a) 3

(1)

(4) 2

(a) 3

F ig u r e 4 a. Immunoelectrophoretic analyses of the IgA preparation (2), porcine milk (3) and swine serum (1) against rabbit antiserum to porcine milk IgA (a) and rabbit antiserum to swine serum (h).

F i g u re $4 \mathrm{~b}$. Immunodiffusion test of swine serum (1), milk IgA (2), milk (3), and sputum (4) against rabbit anti-porcine-milk IgA serum (a). 
of the milk IgA are shown in Figs. $4 \mathrm{a}$ and $4 \mathrm{~b}$. The antiserum prepared against pcrcine milk IgA is showing a reaction of identity between milk IgA and serum IgA suggesting that the antiserum does not react with the secretory component. The rabbit anti-milk-IgA serum obtained with the immunization technique described did not react with IgG and IgM. The relationship of the isolated protein to sputum and milk and a reaction of identity between sputum and milk with monospecific anti-milk-IgA serum are shown in the same figures.

\section{Qualitative immunochemical examination of tracheobronchial secretions}

Immunoelectrophoretic analysis of sputum is shown in Fig. 5.

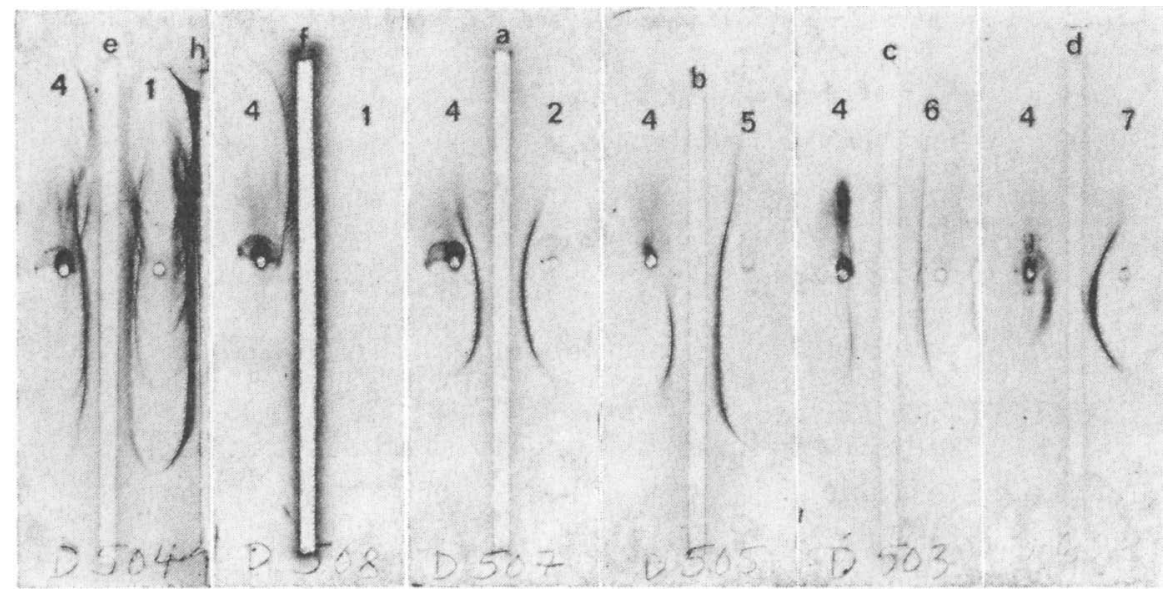

F i g u r e 5. Immunoelectrophoretic analyses of sputum. The symbols refer to the following: $1=$ swine serum, $2=\operatorname{milk} \operatorname{IgA}, 4=$ sputum, $5=\operatorname{IgG}, 6=\operatorname{IgM}, 7=$ transferrin, $\mathrm{a}=$ rabbit antiserum to porcine milk IgA, b $=$ IgG, $c=$ IgM, $d=$ transferrin, $e=$ TBW, $f=$ TBW absorbed with swine serum, and $h=$ swine serum.

Among the immunoglobulins, IgG and IgA are easily detectable. IgM could be shown only by using a monospecific antiserum, probably because of low concentration of this immunoglobulin. Immunoelectrophoresis of sputum showed an arc that was electrophoretically similar to albumin in serum. Two arcs in the $\alpha$-region remained after absorption of the anti-TBW serum with swine serum. The relationship of sputum to IgG, IgA, IgM and transferrin with monospecific antisera in the immunodiffusion test is shown in Fig. 6. 


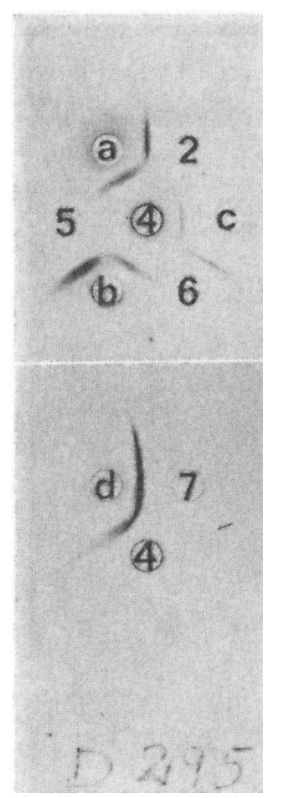

F ig u r e 6. Immunodiffusion tests of sputum. The symbols are the same as in Fig. 5 .

Quantitative estimation of immunoglobulins in tracheobronchial secretions

The results of the immunoglobulin quantitation in TBW are presented in Table 1.

Table 1. Immunoglobulin levels in TBW from 9 normal pigs.

\begin{tabular}{lrrrrrrr}
\hline & \multicolumn{3}{c}{$\mathrm{mg} / \mathbf{1 0 0} \mathrm{ml}$} & & \multicolumn{3}{c}{ Rel. \% } \\
\cline { 2 - 4 } \cline { 6 - 8 } Pig no. & IgA & IgG & IgM & & IgA & IgG & IgM \\
\hline 1 & 29.1 & 26.2 & 2.2 & & 50.6 & 45.6 & 3.8 \\
2 & 20.4 & 29.6 & 2.2 & & 50.2 & 56.7 & 4.2 \\
3 & 42.4 & 28.8 & 6.2 & & 54.8 & 37.2 & 8.0 \\
4 & 142.6 & 11.9 & 15.1 & & 84.1 & 7.0 & 8.9 \\
5 & 26.4 & 8.1 & 2.4 & & 66.7 & 22.0 & 6.5 \\
6 & 29.9 & 9.7 & 1.3 & & 73.1 & 23.7 & 3.2 \\
7 & 54.1 & 30.1 & 4.1 & 61.3 & 34.1 & 4.6 \\
8 & 66.4 & 58.1 & 7.3 & & 50.4 & 44.1 & 5.5 \\
9 & 21.3 & 10.8 & 2.5 & & 61.6 & 31.2 & 7.2 \\
\hline Mean value $\pm \mathrm{s}$ & & & & 61.4 & 33.5 & 5.8 \\
& & & & & \pm 11.7 & \pm 14.8 & \pm 2.0 \\
\hline
\end{tabular}


With exception of pig no. 2, levels of IgA exceeded those of IgG, and the IgG exceeded the IgM vaiues. Compared to the others, pig no. 4 had more IgA and IgM but less IgG. The mean values $\pm \mathrm{s}$ of relative percentage of the total immunoglobulin content are for IgA $61.4 \pm 11.7$, IgG $33.5 \pm 14.8$, and IgM $5.8 \pm 2.0$.

The results of the immunoglobulin quantitation in sputum samples are shown in Table 2.

T a b l e 2. Immunoglobulin levels in sputum from 9 normal pigs.

\begin{tabular}{lcccccccc}
\hline & \multicolumn{3}{c}{$\mathrm{mg} / 100 \mathrm{ml}$} & Total Ig & \multicolumn{3}{c}{ Rel. \% } \\
\cline { 3 - 4 } Pig no. & IgA & IgG & IgM & conc. & IgA & IgG & IgM \\
\hline 1 & 541.7 & 69.8 & 17.5 & 629.0 & 86.1 & 11.1 & 2.8 \\
2 & nd & nd & nd & - & - & - & - \\
3 & 162.4 & 8.0 & 16.5 & 186.9 & 86.9 & 4.3 & 8.8 \\
4 & 597.5 & 51.6 & 23.6 & 672.7 & 88.8 & 7.7 & 3.5 \\
5 & 703.2 & 36.1 & nd & - & - & - & - \\
6 & 277.6 & 50.3 & 9.0 & 327.9 & 84.7 & 15.3 & 2.8 \\
7 & 540.6 & 69.0 & 21.3 & 630.9 & 85.7 & 10.9 & 3.4 \\
8 & nd & nd & nd & - & - & - & - \\
9 & 304.4 & 65.7 & 27.2 & 397.3 & 76.6 & 16.5 & 6.9 \\
\hline Mean & 446.8 & 50.1 & 19.2 & 474.1 & 84.8 & 11.0 & 4.7 \\
value $\pm \mathrm{s}$ & \pm 198.4 & \pm 22.2 & \pm 6.4 & \pm 198.9 & \pm 4.3 & \pm 4.6 & \pm 2.5 \\
\hline
\end{tabular}

nd $=$ not done.

The sputum samples show a great variation in the total immunoglobulin concentration. However, determination of the relative percentage of the total immunoglobulin content gives for IgA $84.4 \pm 4.3, \mathrm{IgG} 11.0 \pm 4.6$ and $\mathrm{IgM} 4.7 \pm 2.5$ (mean values $\pm \mathrm{s}$ )

The IgA average is higher and the IgG average is lower than that found in TBW from the same pigs. The IgM average is low and about the same as that found in TBW.

The quotient between the relative percentage of the immunoglobulins gives an $\operatorname{IgA} / \operatorname{IgG}$ average of 7.7 in sputum and 1.8 in TBW suggesting that IgA is the main immunoglobulin in normal porcine tracheobronchial secretions.

Analytical errors. For IgA the analytical error was calculated from 9 determinations of a control milk serum at different dilutions. The calculated mean value was $283.4 \pm 9.8 \mathrm{mg}$ per $100 \mathrm{ml}$ of milk serum $(\bar{x} \pm \mathrm{s})$ which means an analytical rreor of $3.5 \%$. For IgG the analytical error was calculated from 26 determina- 
376

N. Holmgren

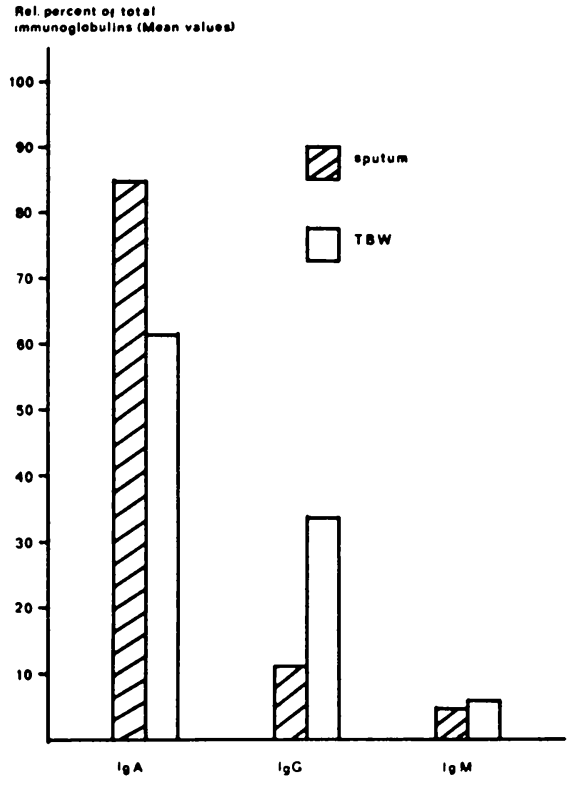

Fig ur e 7. Mean values for IgA, InG and MgM expressed in relative percentage of the total immunoglobulin concentration in sputum and TBW.

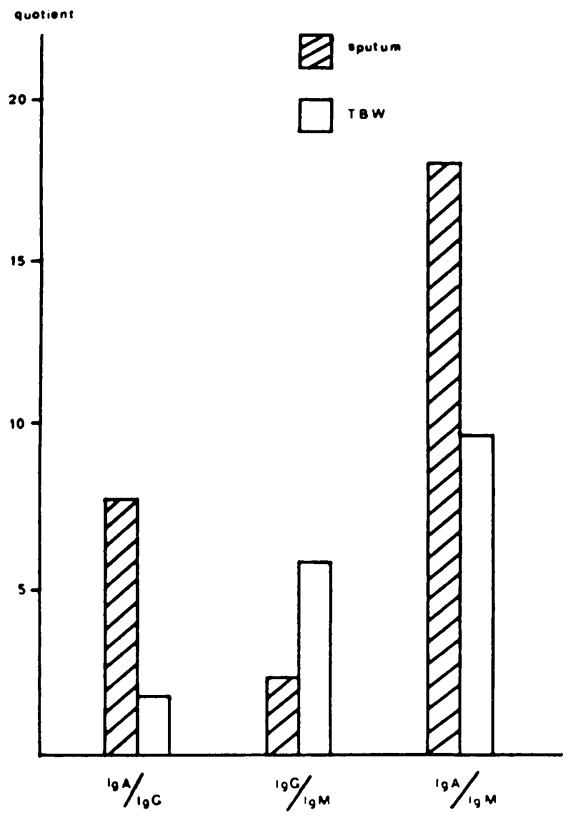

Figure 8. Quotients between the relative percentage of immuneglobulin in TBW and sputum. 
tions of a control serum at different dilutions. The calculated mean values was $2301 \pm 196 \mathrm{mg}$ per $100 \mathrm{ml}$ of serum $(\bar{x} \pm \mathrm{s})$, which means an analytical error of $8.5 \%$. For IgM the analytical error was calculated from 12 determinations of a control serum at different dilutions. The calculated mean value was $125 \pm 11.8$ mg per $100 \mathrm{ml}$ of serum $(\bar{x} \pm s)$, which means an analytical error of $9.4 \%$

\section{DISCUSSION}

Compared to other external secretions, little work has been done on the immunoglobulins in normal tracheobronchial secretions. This is probably due to great difficulties in collection of specimens. In normal individuals the sputum is scanty in amount and difficult to collect without injuring the mucous membrane. The method of collecting sputum specimens by a piece of cotton works well and has also been used by putting a piece of cotton through a bronchoscope into the carina. However, care must be taken to avoid traumatic lesions in trachea, which may result in contamination with blood. In these investigations no red blood corpuscles could be observed either in sputum or in samples of TBW.

All samples were taken during anaesthesia which seems to be necessary because shortly after death there is a transudation of serum into the tracheobronchial tree (Waldman et al. 1968).

Accunate quantitation of immunoglobulins in external secretions is complicated by technical problems when using precipitation techniques. For quantitation of $\operatorname{IgA}$ in secretions it is necessary to use a standard with similar antigenic properties as the tested antigen (Tomasi \& Bienenstock 1968). Use of milk IgA, which is homogenous in gel filtration, as a standard for quantitation of IgA in tracheobronchial secretions does not necessarily give absolute figures because there might be a heterogeneity in molecular size for IgA in sputum. However, it is not likely that this would change the finding of $\operatorname{IgA}$ as the predominant immunoglobulin in sputum and TBW.

The predominant immunoglobulin in tracheobronchial secretions was IgA which accounted for about $85 \%$ in sputum and $61 \%$ in TBW of the total immunoglobulin concentration. This is in agreement with the results obtained in other species (Keimowitz 1964, Masson et al. 1965, Waldman et al., Turgeon et al. 
1969, Lieberman et al. 1970), where the IgA levels exceeded those of IgG and IgM in tracheobronchial secretions.

The IgA/IgG ratio in sputum is $7.7: 1$ and in TBW 1.8:1. The corresponding quotient has been estimated as being $12: 1$ in porcine intestinal juice and 5:1 in porcine gut mucosa (Bourne et al. 1971). In porcine milk the IgA/IgG is about 3.5:1 (Vaerman et al. 1970).

The difference between the IgA/IgG quotient in sputum and TBW is difficult to explain. The sputum samples were collected at the carina. The TBW contained proteins also from the deeper part of the bronchial tree and there might be quantitative differences between the immunoglobulins at different levels of the tracheobronchial tree. On the other hand IgA has been shown to be a constituent of the insoluble bronchial mucous gel (Anzai et al. 1963). Rasche \& Ullmer (1971) subjected sputum to centrifugation, ultrasonics, followed by freeze drying. The fraction obtained after centrifugation alone contained more IgG and less IgA compared to the IgG and IgA levels in the fraction obtained after ultrasonics and centrifugation. This finding indicates that difficulties in releasing IgA from the bronchial mucous gel with homogenization of TBW also may be of importance for the low IgA/IgG quotient in TBW.

By the use of immunodiffusion tests IgM could be detected in sputum and TBW of all pigs tested. In man IgM has infrequently been found in saline washings from the tracheobronchial tree (Keimowitz, Masson et al., Waldman et al., Turgeon et al). This may be due to restricted possibilities in concentrating relatively small samples.

Besides the immunoglobulins, albumin and transferrin could be identified in tracheobronchial secretions. Two other precipitates could be seen in immunoelectrophoretic analysis using anti-TBW serum as antiserum. The absorption of rabbit antiTBW serum with swine serum revealed 2 components in the $\alpha$ region, which seemed to be specific for the bronchial secretions.

The origin of the proteins in sputum and TBW can not be determined judging from these investigations. However, the presence of albumin and transferrin indicates a passage from blood serum into the tracheobronchial tree. The occurrence of immunoglobulins may be due to both such a passage and also a local production, especially of IgA. 


\section{REFERENCES}

Anzai, T., J. Ibayashi, C. M. Carpenter \& L. Hyde: $\beta_{2^{\mathrm{a}}}$-globulin as a molecular constituent of insoluble bronchial mucus gel. Amer. Rev. resp. Dis. $1963,88,503-508$.

Bourne, F. J.: IgA immunoglobulin from porcine milk. Biochim. biophys. Acta (Amst.) 1969, 181, 485-487.

Bourne, F. J., J. Pickup \& J. W. Honor: Intestinal immunoglobulins in the pig. Biochim. biophys. Acta (Amst.) 1971, 229, 18-25.

Chodirker, W. B. \& T. B. Tomasi: Gammaglobulins: Quantitative relationships in human serum and nonvascular fluids. Science 1963, 142, 1080-1081.

Hanson, L. A.: Comparative immunological studies of the immunoglobulins of human milk and blood serum. Int. Arch. Allergy 1961, $18,241-267$.

Jönsson, $A .:$ to be published.

Keimowitz, R. I.: Immunoglobulins in normal human tracheobronchial washings. A qualitative and quantitative study. J. Lab. clin. Med. 1964, 63, 54-59.

Lieberman, P., J. Ricks, L. W. Chakim, J. R. Wardell \& R. Patterson: Immunoglobulins in respiratory secretions obtained from the canine tracheal pouch. Proc. Soc. exp. Biol. (N.Y.) 1970, 135, $713-716$.

Lowry, O. H., N. J. Rosebrough, A. L. Farr \& R. J. Randall: Protein measurement with the Folin fenol reagent. J. biol. Chem. 1951, 193, 265-275.

Mancini, G., A. O. Corbonara \& J. F. Heremans: Immunochemical quantitation of antigens by single radial immunodiffusion. Immunochemistry 1965, 2, 235-254.

Martinsson, $K$.: Immunoglobulin therapy in piglets. A methodological and experimental study. Acta vet. scand. 1970, Suppl. 29.

Masson, P. L., J. F. Heremans \& J. Prignot: Studies on the proteins of human bronchial secretions. Biochim. biophys. Acta (Amst.) $1965,111,466-478$.

Porter, P.: Transfer of immunoglobulins IgG, IgA and IgM to lacteal secretions in the parturient sow and their absorption by the neonatal piglet. Biochim, biophys. Acta (Amst) 1969, 181, 381392.

Porter, P., D. E. Noakes \& W. D. Allen: Secretory IgA and antibodies to Escherichia coli in porcine colostrum and milk and their significance in the alimentary tract of the young pig. Immunology $1970,18,245-257$.

Rasche, B.\&W.T. Ullmer: Untersuchungen über die Zusammensetzung des Bronchialschleimes bei chronisch obstruktiver Bronchitis. (The composition of bronchial mucus in chronic-obstructive bronchitis). Pneumonologi 1971, 144, 10-32.

Richardson, A. K. \& P. C. Kelleher: The $11 \mathrm{~S}$ sow colostral lg. Isolation and physico-chemical properties. Biochim. biophys. Acta (Amst.) 1970, 214, 117-124. 
Scheidegger, J. J.: Une microméthode de l'immuno-électrophorèse. (A micro-method of immuno-electrophoretic analysis). Int. Arch. Allergy 1955, 7, 103-110.

Tomasi, T. B., E. M. Tan, A. Solomon \& A. Prendergast: Characteristics of an immune system common to certain external secretions. J. exp. Med. 1965, 121, 101-125.

Tomasi, T. B. \& J. Bienenstock: Secretory immunoglobulins. Advanc. Immunol. 1968, 9, 1-96.

Turgeon, P., F. Turgeon \& J. Robert: Les immunoglobulines sécrétoires trachéo-bronchiques. (Immunoglobulins in tracheobronchial fluids). Un. méd. Can. 1969, 98, 934-939.

Turgeon, P., J. Robert \& F. Turgeon: Étude des immunoglobulines sériques et sécrétoires trachéo-bronchiques. (Study of serum and secretory tracheobronchial immunoglobulins). Un. méd. Can. 1971, 100, 232_239.

Vaerman, J. P., J. B. Arbuckle \& J. F. Heremans: Immunoglobulin A in the pig. II. Sow's colostral and milk IgA: Quantitative studies and molecular size estimation. Int. Arch. Allergy 1970, 39, 323333.

Wadsworth, C.: A slide microtechnique for the analysis of immune precipitins in gel. Int. Arch. Allergy 1957, 10, 355-360.

Waldman, R. H., J. J. Mann \& J. A. Kasel: Influenza virus neutralizing antibody in human respiratory secretions. J. Immunol. 1968, $100,80-85$.

\section{SAMMANFATTNING}

Immunoglobuliner $i$ tracheobronchialsekret hos normala grisar.

Metoder att samla sputum och tracheobronchial spolvätska beskrivs. Proteiner i normala tracheobronchiala sekret hos svin studeras med immunokemiska kvalitativa och kvantitativa metoder. Bland immunoglobulinerna identifieras IgA, IgG och IgM. Immunoelektroforetisk analys av sputum visar albumin, transferrin och $\mathrm{i} \alpha$-regionen två komponenter vilka ej kan påvisas i serum. Det dominerande immunoglobulinet i tracheobronchiala sekret är IgA, som utgör cirka $85 \%$ av den totala immunoglobulinkoncentrationen i sputum och cirka $61 \%$ av totala immunoglobulinkoncentrationen i tracheobronchial spolvätska.

(Received August 21, 1972).

Reprints may be requested from: Nils Holmgren, Department of Medicine I, Royal Veterinary College, S-104 05 Stockholm 50, Sweden. 